volved problems of supersonic wing theory and wing/body interference, which led on to his work on swept wings, to his complementary oxperimental programmo and to his active interest in the application of numerical methods and modern digital computers to outstanding problems in fluid dynamics. It is of considerable interest to note that Dr. Lock's work is in direct line of descent from the work that his father, the late C. N. H. Lock, pioneored at the National Physical Laboratory in the 1930's.

\section{National Instrument Service in Britain}

THE Science Research Council, in collaboration with the Ministry of Technology and the Office of Scientific and Technical Information, set up earlier this yoar a Panel under the chairmanship of Prof. G. Porter (University of Sheffield) to consider the feasibility and economics of a centralized national instrument service. A number of expensive, physicochemical instrumonts could provide a rapid service of routine measurements, on a repayment basis, for all scientists, such as those in Govornment, industrial and university laboratorios. This service would onablo physical-analytical techniques to be more widely available than at present and would thereby encourage the use of new instrumontal techniques. Such a centralized arrangomont would have additional advantages, particularly if it were associated with an interpretation service and data-store facilities. The Panel is hoping to find out whethor such a service would be an effective means of meeting more economically the growing needs of research scientists for routine measurements on increasingly expensive research instruments. A description of some services which might be offered is being circulated, together with a brief questionnaire, to a cross-section of potential customers. The answers receivod will cnable an assessment to be made of the need for services of this kind and of their economic viability. When this assessment has been thoroughly studiod, the Panol will make recommenda. tions to the Science Research Council regarding any future action.

\section{Cambridge Engineering Freshmen}

IT is too early to know the state of this year's ontry of students into tho tochnological faculties of all universitios and colleges of advanced technology, but a fact which should cheer industry is that at the University of Cumbridge the number of freshmon ontoring the Engineering Department is 304, the highest in any year since the Mechanical Sciences Tripos was established in 1892. The exceptional quality of these mon is indicated by the fact that 208 of them have been admitted to the fast stream which enables them to complete the course loading to the Mechanical Scioncos Tripos Part I after two years of study instead of the normal three. As recently as 1960 the rate of freshmen entering the fast stream was only about one-third of the total intake.

\section{I.C.S.U. Bulletin}

The I.C.S.U. Bulletin (No. 4; July 1965), issued by the International Council of Scientific Unions, contains a brief account of the third meeting of the Executive Committoo of the International Council of Scientific Unions, to which was presented a report on the Scientific Committee on Oceanic Research. There has been a steady increase in the activities of this Committee, which now has twenty-sevon national adhoring institutions. A report was also prosonted from the Scientific Committee on Antarctic Research, and a discussion on the work of this Committee directed attention to the noar oxtinction of some species in Antarctica duo to officient and intensive fishing oporations, and it was suggested that the restricted areas around Antarctica should be extended from 3 to 10 miles. The Exocutivo Committee agroed that immediato action was necessary to prevent certain whales, particularly the blue whale, from becoming extinct. It also discussed at length the inereasing importance of solar terrestrial physics and the activitios of the Intor-Union Commission on Solar Terrestrial Relations, its terms of referonce and membership. A report was also presented from the Working Group on Rolations with Developing Countries, and the suggestion was made that scientists from advanced countries should be encouraged to undertake missions in the devoloping countries. Sciontists from the latter countries should be assisted to enable them to attend international meetings. The Bulletin also contains news from the scientific unions, including reports on: the work of the Committee on Atmospheric Sciences; the work of the Naplos Zoological Station; the International Union of Biochemistry; and other roports from the Scientific Committee on Oceanic Research, the Committce on Space Rosoareh, the Federation of Astronomical and Geophysical Services, tho Specigl Committoe for the International Years of the Quiet Sun, and on the International Committee for Geophysics. There is also a list of publicetions, and the usual calender of meetings for August 1965-January 1966.

\section{International Paper Size}

THe proposed change-over to the metric system in Britain will necessarily take a long time for full realization and it will pose many practical problems, both industrial and domestic. Not the least of thoso is the effect on paper sizes and printing, where tradition is likely to die very hard. If the proposed scheme of the metric-based 'International Paper Sizes' is adoptod, it will completely revolutionize the present practice of the printing and publishing trades, with consequent repercussions in commerce, professional and private customs, particularly where books, pamphlets, display leaflets, stationery and envelopes are concerned, to mention only a few of the items involved. The keyword bohind the conception of 'International Paper Sizes', as it is known, is simply rationalization. It means ". . . the introduction of a complotely new rango of paper sizes, from small to large, each based upon a metric measure and each related, in logical sequence and proportion, to the rest of the range". One result, porhaps not unwelcome, will be the replacement of the time-honourod words 'quarto', 'crown', 'octavo', etc., by a numerical code, which will be universally understood. An impartial and non-technical exposition of the definitions, advantages and disadvantages of the 'International Paper Sizes' system has recently been published in the form of a booklet entitled Paper at Work Number 4: International Paper Sizes (A Series of Spicer's Guides. Pp. 8. London: Spicers, Ltd., 1965). Included in this booklet is a full-sized $A 1$ sheet $(23.4 \mathrm{in} . \times 33.1 \mathrm{in.})$, which is half the $A 0$ size of 1 square motre. This $A 1$ sheet is folded to demonstrate physically the full sizes of $A 2, A 3, A 4$ and $A 5$ and their relationship to each other. This example adequately illustrates the now code; the system is based on three series of sizes-all of the same proportion-designated $A, B$ and $C$. The $A$ series is perhaps the most widely used, for example, for stationery and general leaflet printing; the $B$ series is intended primarily for larger printed items such as posters, wallcharts, etc.; the $C$ series, in conjunction with somo of the $B$ sizes, is intended for envelopes. In the ultimate adoption of this 'International Papor Size' system there are undoubtedly benefits of cost, convonience, inter. national standardization and simplification. The disadvantages also have to be faced, but in the long run should not prove insuperable; for oxample, some printers' machinery may not be geared to handle 'International Paper Size' with optimum productivity; also office filing, filing equipment, addressing machines, otc., may not be suitable for dealing with 'International Paper Size'sizes; but these hazards will be overcome eventually, and meanwhilo ovorybody concerned has time for considoration and thoughtful reappraisal of the important 